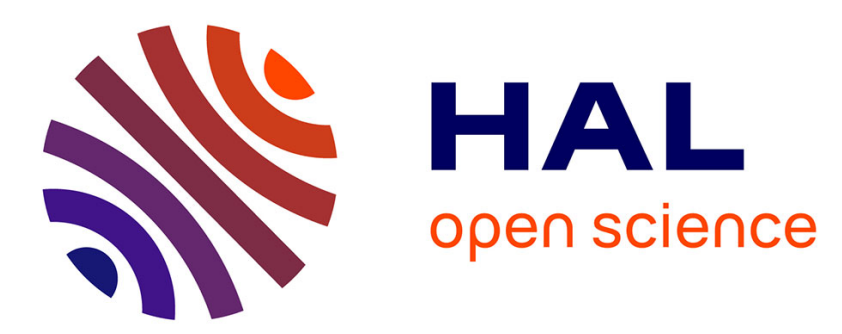

\title{
The Role of Social Networks in Online Marketing and Measurement of Their Effectiveness - The Case Study
}

Hana Mohelska, Marcela Sokolova

\section{To cite this version:}

Hana Mohelska, Marcela Sokolova. The Role of Social Networks in Online Marketing and Measurement of Their Effectiveness - The Case Study. 17th Conference on e-Business, e-Services and e-Society (I3E), Oct 2018, Kuwait City, Kuwait. pp.13-20, 10.1007/978-3-030-02131-3_2 . hal-02274156

\section{HAL Id: hal-02274156 \\ https://hal.inria.fr/hal-02274156}

Submitted on 29 Aug 2019

HAL is a multi-disciplinary open access archive for the deposit and dissemination of scientific research documents, whether they are published or not. The documents may come from teaching and research institutions in France or abroad, or from public or private research centers.
L'archive ouverte pluridisciplinaire HAL, est destinée au dépôt et à la diffusion de documents scientifiques de niveau recherche, publiés ou non, émanant des établissements d'enseignement et de recherche français ou étrangers, des laboratoires publics ou privés. 


\title{
The role of social networks in online marketing and measurement of their effectiveness - the case study
}

\author{
Hana Mohelska ${ }^{\text {[0000-0003-0441-0712] }}$ and Marcela Sokolova ${ }^{*}[0000-0002-0641-7750]$ \\ Faculty of Informatics and Management, Department of Management, University of Hradec \\ Kralove, Hradec Kralove 3, Rokitanskeho 62, Czech Republic \\ *Corresponding author: hana.mohelska@uhk.cz \\ marcela.sokolova@uhk.cz
}

\begin{abstract}
This paper is devoted to online marketing tools and primarily focuses on the use of social networks and measuring their effectiveness. The theoretical part briefly presents the topic of online marketing and selected tools. The next section deals with the case study that analyses the use of social networks on a particular project, including measuring the efficiency of social networks by comparing the planned and actual state according to the selected metrics. In conclusion, there is a discussion on the results obtained and the possible directions, which would increase the efficiency of social networks, i.e. online marketing, are outlined. The results of assessing the current state of online marketing for the surveyed project in 2017 , by comparing the planned and actual metric values, largely fail to meet the targets. With measuring social networking tools, the planned numbers of website visits and social networking orders didn't reach their planned values. Regarding the number of fans on individual social networks, the planned status was only achieved with the Pinterest and Instagram social networks.
\end{abstract}

Keywords: Online marketing, social networks, efficiency measurement, Facebook, Twitter, Instagram.

\section{Introduction}

The rapid development of information and communication technologies, in which, the Internet plays an important role, has been an important trend in the recent years. Nowadays, only a few people can imagine life without Internet. The possibilities of using the Internet include real-time communication between people, access to a wide range of information and services and it has a great potential mainly for entrepreneurship, even for businesses that normally operate outside the Internet. Today, the vast majority of businesses are presented on the Internet. Thanks to online marketing, they have a better chance of entering people's awareness and increasing their sales.

The present time brings enhanced possibilities of marketing communication through the Internet. Communication on the Internet is characterized by a number of positive characteristics, particularly through the ability to accurate target, personalize, interact and measure, and all with relatively low costs. [1] [2]. 


\section{Objective and methodology}

The submitted study's aim was to evaluate the current state of online marketing for the selected project. An assessment of the current state of online marketing was carried-out in 2017 on three major tools - social networks, PPC advertising and e-mailing - this paper primarily focuses on social networking findings.

\subsection{The analyzed project presentation}

The case study for the demonstration of measuring social networking effectiveness was carried-out on a selected start-up project. It is an exclusive platform that connects the selected designers and enthusiasts who love original design and can appreciate creative work. Within this project, it currently exhibits around 500 designers from around the world. So far, the project works mainly within the Czech Republic and Slovakia.

\subsection{Social networking efficiency measurement}

The tools were evaluated in 2017 by comparing planned and actual metric values. The evaluation data was obtained from Google Analytics, Google AdWords, MailChimp, and the project's website. [3] [4]

\section{Theoretical background - online marketing tools}

The marketing definition from Kotler's point of view states that marketing is a science and an art to discover, create and deliver value that meets the needs of the target market. Marketing identifies unfulfilled needs and requirements. It defines, measures and quantifies the scope of the selected market and the potential profit. It precisely determines which market segments the company can maintain best, it designs and promotes appropriate products and services. [5] [6]

The Internet provides companies with new opportunities and benefits from a marketing perspective. These include, for example, the provision of important information, a new sales channel and the promotion of business activities and products around the world, the ability to customize the offer via database information on the number and frequency of site visitors and many others. Linking Internet and marketing therefore creates a significant area. [7] [8] [9]

\subsection{Electronic commerce}

Active marketing and the sale of goods and services on the Internet is referred to as ecommerce. Thanks to the Internet, today's world is characterized by inter-connection, which brings new methods, such as identifying or searching for customers, how to distribute products more effectively, or how to communicate more effectively with large groups of customers. [10] [11] 
The main factors that have influenced the development of e-commerce, include the following four factors: 1) Digitization and networking; 2) Rapid Internet development; 3) New forms of trading; 4) Adapting products to customer needs.

E-business. E-business includes all electronic information exchanges via electronic platforms (intranet, extranet, Internet) to conduct business activities. The Internet and other technologies help businesses to conduct their business activities faster, more accurately and in a greater time and space range. [12] [13]

E-commerce. E-commerce is a more specific term that includes sales and purchasing processes using electronic communication. Electronic markets are used to represent market venues and vendors use them to offer their products and services online. Ecommerce includes e-marketing and e-purchasing (the "shopping" site of e-commerce). [12] [14]

E-marketing. E-marketing or electronic-marketing is the "selling" e-commerce site and involves communication, sales promotion and sales of goods and services through the Internet. It represents the effort of the company to inform on the products and services, to promote them and to sell them. [12] [15]

\subsection{Online marketing elements}

SEO. SEO, i.e. website optimization for search engines or optimization of search-ability on the Internet, is an abbreviation of the Search Engine Optimization in English. A more detailed definition of SEO is explained by SEO consultant Pavel Ungr, who says SEO is the process of influencing the visibility of the website in the unpaid part of the search engine results. Generally speaking, the higher and the more often the web appears in the search engine results, the more visitors the web can get from the Internet search engine. SEO can target different types of search including images, local search, videos, academic information, news, or narrower search in specific fields. [16] [17]

Link-building. Link-building is an activity that aims to establish a partnership where reference is made in the form of a link, text or image, leading to the promotion of websites in places where potential customers look for them. The authority of website is created during link-building. [18]

Content marketing. Content marketing means regular creation and the sharing of quality free-of-charge content among listeners who share it and it will be useful to them or entertain them. Quality content related to the company's business scope will attract potential customers who will become more interested in the company. Then, they can become customers and if customers are satisfied, the customers become returning clients. By publishing high-quality educational content, the company gains the confidence of customers who want to do business with it. [19]

Copywriting. Copywriting is a creative activity that creates gentle and engaging advertising and marketing texts that sell products and services. [20] 
Conversion rate optimization. Optimizing the conversion rate means adjustments to the website to increase the conversion rate. Conversion is an indication of a fact when a web visitor becomes a customer, most often it includes an order. [20]

Social networks. Social networks are an online social media where users create and share a variety of content, such as photos, videos, personal experiences and opinions. Companies on social networks create content and communicate with potential customers to promote brands and marketing goals. [1] [20]

PPC advertising. PPC is the abbreviation for the English term "Pay Per Click". This is a business model when the advertiser pays for every click on the ad.

E-mailing. Newsletter is an English term for an electronic newsletter regularly sent to logged-in subscribers and it belongs to a modern, inexpensive and effective marketing tools. Everyone, who receives a newsletter, is a potential customer. At the same time, it also serves for the dissemination of the company's awareness and its further growth. [21] [22]

\subsection{Measurement and evaluation of online marketing tools}

Online marketing is a powerful tool due to the possibility of accurate monitoring of target customers. The advantage of online activities is that they are relatively easy to measure.

The metrics of different tools and campaigns are also different depending on the given goals to be achieved. The most significant metrics include site traffic, conversions, i.e. desirable site visitor's actions, average time spent on the site, the number of pages visited by the user, the site instant exit rate and others. The metrics need to be analyzed using the tools for that purpose. The most common metrics tracking tool on the web is Google Analytics, then Google AdWords tool for PPC advert, e-mailing such as MailChimp, on social networks like Facebook, the Facebook Insights tool is used.

\section{Assessing the current state of social networking as an online marketing tool - the case study}

The tools were evaluated by comparing planned and actual metric values in 2017 . The evaluation data was obtained from Google Analytics, Google AdWords, MailChimp, and the project's website.

To measure the effectiveness of the social networking tool, the following table (Table 2) lists the number of visits and the number of orders that are made from individual social networks. Website traffic through social networking channels was estimated to 8,593 visits in 2017 and accounted for $14.16 \%$ of the total traffic. By clicking through the social networks, 28 conversions were carried out in the form of orders for design products. What is important here is the fact that none of the social networks have been financially subsidized, so they are only organic unpaid results. 
Table 1. Website traffic from social networks and number of orders leading from social networks in 2017. (Google Analytics, customized processing)

\begin{tabular}{lllll}
\hline Social Network & Traffic & Share of total traffic & Number of orders & Share of total orders \\
\hline Facebook & 6271 & $72.98 \%$ & 11 & $39.29 \%$ \\
Pinterest & 1914 & $22.27 \%$ & 7 & $25.00 \%$ \\
Instagram & 102 & $1.19 \%$ & 2 & $7.14 \%$ \\
LinkedIn & 88 & $1.02 \%$ & 6 & $21.43 \%$ \\
Twitter & 88 & $1.02 \%$ & 2 & $7.14 \%$ \\
Tumblr & 1 & $0.01 \%$ & 0 & $0 \%$ \\
\hline
\end{tabular}

The comparison of the planned and actual state is used to evaluate this tool. The following table (Table 3) shows that the estimated number of site visits and the number of social networking orders scheduled was far from being achieved.

Table 2. Scheduled and actual number of visits and orders from social networks in 2017. (Google Analytics, project website, customized processing)

\begin{tabular}{ll}
\hline & Social networks \\
\hline Scheduled visits & 50000 \\
Visits & 8464 \\
Planned number of orders & 500 \\
Number of orders & 28 \\
\hline
\end{tabular}

An important social networking tool metric is also the number of fans who express interest from a potential customers' point of view. The next table (Table 4) lists the scheduled and actual numbers of fans on each social network. Fulfilment of the planned values were carried-out only on the Pinterest and Instagram social networks.

Table 3. Social networks - fan number values in 2017. (Facebook.com, Pinterest.com, Instagram.com, Twitter.com, Linkedin.com, customized processing)

\begin{tabular}{llllll}
\hline & Facebook & Pinterest & $\begin{array}{l}\text { Insta- } \\
\text { gram }\end{array}$ & $\begin{array}{l}\text { Twit- } \\
\text { ter }\end{array}$ & LinkedIn \\
\hline Fan Schedule Plan for 2017 & 130000 & 3500 & 1500 & 1500 & 50 \\
Fans at the beginning of 2017 & 112570 & 2516 & 699 & 1150 & 5 \\
Fans at the end of 2017 & 115396 & 3521 & 1956 & 1270 & 23 \\
\hline
\end{tabular}

However, for all social networks, the number of fans had a growing character (Fig. 1), also reflecting the work of a social networking specialist, who tried to influence these numbers with their activity on social networks. 


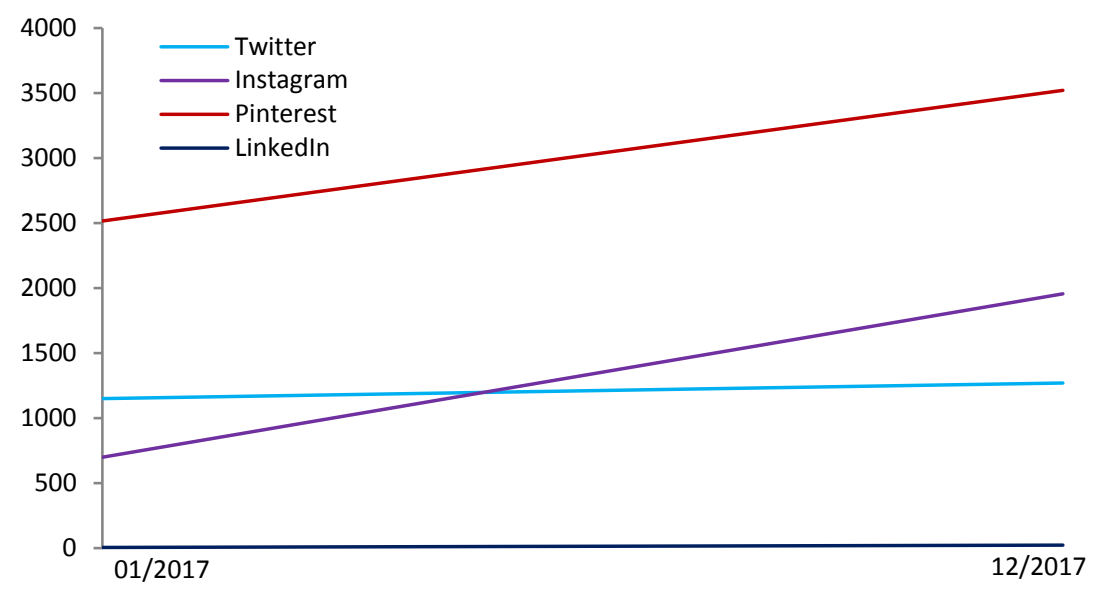

Fig. 1. Development of fan numbers on the following social networks - Pinterest, Instagram, Twitter and LinkedIn in 2017. (customized processing)

The social networking tool is used extensively within the scope of the project, in terms of the number of social networks on which it operates. From the point of view of shared network contributions, broader sharing options could be used - a broader type of content, or a wider focus on target groups, their interests, and so on.

\section{Discussion}

The aim of the submitted study was to evaluate the current state of online marketing for the selected project. Firstly, the project was introduced, subsequently an assessment of the current state of the use of social networking in online marketing in 2017 was carried-out concerning three important tools - social networks, PPC advertising and emailing - the paper's focus was primarily on social networks. Based on data from Google Analytics, Google AdWords, and MailChimp, the scheduled and actual metric values for each tool were compared.

The assessment results for the current state of online marketing of the project under review in 2017, by comparing the scheduled and actual metric values of the three selected tools largely failed to reach their targets.

With measurements of social networking tools, the scheduled number of website visits and social networking orders didn't reach their expected values. Regarding the number of fans on individual social networks, the planned status was only achieved by the Pinterest and Instagram social networks.

Within PPC advert measurement it was discovered that the estimated number of visits and clicks on adverts were only fulfilled for the campaign on the awareness of the brand in the content network (for the Czech Republic and Slovakia). The planned number of orders resulting from the PPC ad click wasn't reached by any of the campaigns carried-out. 
When measuring e-mailing, it was discovered that the planned number of newsletter subscribers wasn't reached by one target group. The lack of content and capacities were the reason why the other target groups failed to meet the planned number of newsletters sent. The estimated average rate of opening newsletter was fulfilled only for designers in the Czech Republic and Slovakia, and the estimated average click-through rate in the newsletter was reached only for the target group of design lovers in the Czech Republic and Slovakia. The planned numbers of orders resulting from the newsletter click-out were not reached for one target group.

We consider the value of the number of orders on the web as the most important metric as it brings profit to a business. Nevertheless, the values of the planned order numbers didn't reach the planned target in any of the measured tools, on the contrary, these values are very distant to the planned state. Low order values are attributed to different purchasing behavior as they are higher priced products. The reason for not achieving the planned situation is also the fact that more financial investments and capacities were originally planned for the planned activities and the metric values.

So, it is important to realize that the project under consideration as a start-up conceals a great deal of human capacity and total commitment to the given project. In order to achieve business and marketing goals for 2018, it is also necessary to invest sufficient funds to enable the implementation of planned communication activities. The project should continue to focus on presenting its brand, designers and products offline as today's trends show that being online is not as competitive as it used to be. The project could also focus on events in Slovakia, where the design area is experiencing a boom. Due to the high prices of the offered design products, it could also target products with lower value to make them more accessible to a wider range of customers.

\section{Conclusion}

At the time of the boom of information and communication technologies, it is important for each organization to use the potential which is offered to them, because that's the only way they can compete in a competitive battle.

Sufficient efforts and financial investment in meaningful communication activities will later return to the organizations in the form of satisfied customers and increased profitability.

Acknowledgments: The paper was written with the support of the specific project 6/2018 grant "Determinants of cognitive processes impacting the work performance" granted by the FIM UHK and thanks to help of students Aneta Machačková.

\section{References}

1. Karlíček, M., Král, P.: Marketingová komunikace: jak komunikovat na našem trhu. Grada, Praha (2011).

2. Mohelská. H., Sokolová, M.: Smart, connected products change a company's business strategy orientation. Applied Economics. 48(47), p. $4502-4509$ (2016). 
3. Grant, R. M.: Contemporary strategy analysis: text and cases. 7th ed. Hoboken, N.J.: Wiley, xvi, 926 p., (c2010).

4. Grappone, J., Gradiva, C.: Search engine optimization: an hour a day. 3rd ed. Indianapolis, Ind.: Wiley Pub., 408 p., (c2011).

5. Kotler, P.: Marketing v otázkách a odpovědích. CP Books, Brno (2005).

6. Sokolová, M., Zubr, V. Innovation as a Requirement for Business Competitiveness - Czech Republic Case Study. Advanced science letters. American scientific publishers, 2015. DOI: https://doi.org/10.1166/asl.2016.6694

7. Kotler, P., Keller, K. L.: Marketing management. Grada, Praha (2007a).

8. Strauss, J., El-Ansary, A. and Raymond, F. E-Marketing - Fourth Edition. Prentice Hall, New Jersey (2005).

9. Charlesworth, A.: Internet Marketing: a practical approach. Routledge (2011).

10. Chaffey, D., et al.: Internet Marketing. Strategy, Implementation and Practice. Redwood Books Limited, Trowbridge (2000).

11. Boon-Long, S., \& Wongsurawat, W.: Social media marketing evaluation using social network comments as an indicator for identifying consumer purchasing decision effectiveness. Journal of Direct, Data and Digital Marketing Practice, 17(2), 130-149 (2015). https://doi.org/10.1057/dddmp.2015.51

12. Kotler, P.: Moderní marketing: 4. evropské vydání. Grada, Praha (2007b).

13. Yadav, M., Kamboj, S., \& Rahman, Z.: Customer co-creation through social media: The case of 'Crash the Pepsi IPL 2015'. Journal of Direct, Data and Digital Marketing Practice, 17(4), 259-271 (2016). https://doi.org/10.1057/dddmp.2016.4

14. Gupta, A., \& Dhami, A. Measuring the impact of security, trust and privacy in information sharing: A study on social networking sites. Journal of Direct, Data and Digital Marketing Practice, 17(1), 43-53 (2015). https://doi.org/10.1057/dddmp.2015.32

15. Leonhardt, J. M.:Tweets, hashtags and virality: Marketing the Affordable Care Act in social media. Journal of Direct, Data and Digital Marketing Practice, 16(3), 172-180 (2015). https://doi.org/10.1057/dddmp.2015.4

16. Ungr, P.: Definice: Co je SEO - optimalizace pro vyhledávače? http://blog.bloxxter.cz/definice-co-je-seo/ last accessed 2017/01/27.

17. Landers, B.: The Measure of SEO Success Is Revenue, Not Your Google Website Ranking. Air Conditioning Heating, 251 (3), 24-24 (2014).

18. Podstavec, F.: Co je linkbuilding a kdo je linkbuilder? http://www.podstavec.cz/co-jelinkbuilding-a-kdo-je-linkbuilder/, last accessed 2017/01/27

19. Content marketing. Copyblogger, http://www.copyblogger.com/content-marketing/, last accessed 2017/02/01.

20. Mencák, T.: Online marketing v praxi - Online marketing mix (přednáška) Hradec Králové, CS Technologies, s.r.o., UHK, (2016).

21. Finklestein, R.: 49 marketingových tajemství pro zaručené zvýšení prodeje. Computer Press, Brno (2010).

22. Newsletter. Adaptic, http://www.adaptic.cz/znalosti/slovnicek/newsletter/, last accessed 2017/02/03. 